Voix et Images

volxetimages

\title{
Poèmes inédits de Guy Lafond (1958-1970)
}

Volume 4, numéro 2, décembre 1978

Guy Lafond

URI : https://id.erudit.org/iderudit/200150ar

DOI : https://doi.org/10.7202/200150ar

Aller au sommaire du numéro

Éditeur(s)

Les Presses de l'Université du Québec

ISSN

0318-9201 (imprimé)

1705-933X (numérique)

Découvrir la revue

Citer ce document

(1978). Poèmes inédits de Guy Lafond (1958-1970). Voix et Images, 4(2), 189-191.

https://doi.org/10.7202/200150ar d'utilisation que vous pouvez consulter en ligne.

https://apropos.erudit.org/fr/usagers/politique-dutilisation/ 


\section{Poèmes inédits de Guy Lafond (1958-1970)}

Note:

Exhumer, non pas exhausser!

Ces feuillets en jachère, ce limon sédimentaire!

Voici qu'une main prude fouille le billon pour

quelque vestige... ces éteules!

Qu'hier ne retarde pas ces lendemains qui nous pressent!

G. Lafond

\section{JANUS}

$1-$

C'est moi de mon œil allongeant ton regard

Moi plus ferme instant aux confins des clartés

Mirant d'autres miroirs aux mirages fuyants

- Remisez les consonnes, c'est l'œil qui importe J'ajoute un pourtant indicible au-delà

Au feu de mon chant qu'attise le temps.

Eil irradié, musique, vision

Au for d'un levant qui de soi s'y annule C'est moi de lumière accoudé sans égards

A l'orbite incandescent d'un œil qui s'ignore. Janus de lumière s'accorde à l'incessant Par le nom et le verbe et d'ultimes désormais.

2 -

Dès qu'aussitôt faillible a vaincu

L'espace fidèle à d'anciennes mémoires

La parole a vidé au fil d'un cadran

Les heures millénaires en méridiens glacés.

De mille saisons repues aux après embusqués

La nuit broute les pensées de soleils répudiés. 
Un crâne, ou l'intime conjonction il fut il sera Mêlant aux miroirs un ceil importuné

- Distances brouillées au regard réversible et double d'on sait on ne sait plus infiniment Extensible - Janus fatidique désocculte illusoire L'équinoxe rompu en futiles grimoires.

$3-$

Un rapport s'est blessé à d'autres cohésions Un rien précipité aux aubes irréfléchies Sait parmi les eaux enclore son écrin Mobile et tu. Quel mortel désormais Aux miroirs éclatés prolonge de son aile Un limon ni et sans pour feindre un pareil.

C'est moi de mon œil parcours de l'instant Au plus que rompu par cîme de se taire Où me livre un poème qui brûle de musique et mesure l'autant au cœur de l'aussi.

Esclave depuis soudain jusqu'à l'éternité Je est plus haut qui te scande immobile.

\section{PAYSAGES}

Le printemps exhume un cri arboréal

L'aurore se gonfle de neiges balafrées

De serpents érectiles

Mains surgies du fleuve alerté

Sous le point-à-la-ligne.

L'hiver n'est que prélude

Aux vertes levées de voiles

Où dort un froid soleil

Dessous...

On dirait un vent muré

Un poing ocreux

La musique haltée

D'un tambour belliqueux

Une meute d'écume

Une menace d'oiseaux

Et la gorge renversée

D'orgues océanes

Sous l'ogive d'un feu

Une rive incisive

On dirait un cri noir

Un arbre en son noyau 


\author{
Et mu de mollesse \\ On dirait un poème \\ Rêvé aux majuscules! \\ Cristal d'écume \\ que je hume \\ arbre au bosquet \\ affre au beffroi \\ Cire cristalline \\ ample main d'eau \\ alerte frondaison \\ d'une haleine \\ vestige de vestale \\ aveuglant un soleil \\ qui s'y brise. \\ Midi se lasse du poids des soleils... \\ Un creuset de lumière \\ et minuit brûle au sommeil blanc \\ la lune mord au vif d'un sursis \\ ce creux au firmament \\ Un lacis d'eau froisse une aurore blessée \\ et ce tamis d'azur n'est autre \\ que le regard contraint de l'immortel \\ a fuir le ciel.
}

